\title{
EDUCATION FOR A HEALTHY LIFESTYLE IN FREE TIME
}

\begin{abstract}
The purpose of this paper is to present the issue of education for a healthy lifestyle based on examples of the Polish society cultural behaviours as the ideation foundation of actions applied in the post-modern culture at the turn of the 2oth and 21st centuries. The problem of research is set in the interpretative paradigm of humanistic, social sciences. A qualitative method was applied in the process of scientific research (the qualitative analysis of a text/qualitative analysis of documents), in which a hermeneutic understanding and source text interpretation is relevant. The analyses are based on historical printed sources (original materials) and scientific works concerning the issue indicated in the title.
\end{abstract}

Keywords: free time; health; healthy lifestyle; education; pedagogy of free time; history of education.

\section{Introduction}

The category of free time has become popular in the global dimension only since the middle of the 20 century, especially in connection with the discussions of the International Conference of the United Nations Organization concerning the matter of Education, Science and Culture (UNESCO) in France (Annecy \& June, 1957). Obviously by then the concept of free time had already been defined in scientific literature. An example may be the definition of the American economist, sociologist Thorstein Veblen (1857-1929) who stated that free time covered "the whole life beyond work" (Tauber, 1998, p. 18). It should be emphasized that one of

* PhD habil. Edyta Wolter, associate professor at the Cardinal Stefan Wyszyński University in Warsaw, Poland, Faculty of Education; e-mail: e.wolter@uksw.edu.pl. 
the most often quoted definitions of free time in the postmodern culture was created by Joffre Dumazedier (1915-2002), who was interested in sociological research on free time in France. According to Dumazedier free time is "activity that a human being may undertake out of choice or to rest, to entertain, develop skills or education (selfless), voluntary participation in social life after freeing from professional, family, social obligations" (Tauber, 1998, p. 19; compare Pater, 2015, p. 14). It refers to all activities that are undertaken selflessly (based on a given person's decision) beyond family, professional and social obligations (Woronowicz \& Apanel, 2010, p. 20; compare Kwilecki, 2011, p. 8).

Free time fulfills the following functions: rest/recreation (in connection with the renewal of the humanbody's vital forces), fun and entertainment and the function of spending time together. The following aspects of free time were specified: psychological (satisfaction after the hardships of work and learning), sociological (social interactions), pedagogical (self-work, personality growth for a balanced spending of free time) (Matyjas, 2003, p. 561). Especially in case of youth and children also the physiological and health aspect should be accounted for (protection from loss ofhealth) and economic aspect (ensuring a sufficient amount of free time) (Tauber 1998, p. 20).

Work in free time has the integrating and cultural meaning (Pięta, 2008, p. 247). The most popular forms of spending free time are: artistic works, DIY works, social plays and events, collecting, physical activities (for example walking, nordic walking, running, kayaking, yoga, biking, swimming), social activity (Kwilecki, 2011, p. 30-33). Recreational tourism or intellectual development thanks to the development of interests is a very good method of spending free time.

In the postmodern/postindustrial culture of the society of knowledge health is a value and also a subject of all categories of attitudes in their cognitive, emotional and acting aspect. The aspects that define the quality of health in the entropically changing situations of a human life, the lifestyle represents the most crucial factor (circa 50\%) (Wolski, 2009, p. 7), then the genetic conditions (circa 20\%) followed by environmental conditions (circa 20\%) and health service (circa 10\%) (Gaweł, 2003, p. 11-18). Attitudes towards health shape gradually in the process of an individual growth, starting with the initial socialization in the period of the early childhood, when the child experiences the first culture codes, watches personal patterns specific for social behaviour (especially in the family and local environment), then in the next stadiums of a human development in the process of conquering/fighting/ solving natural developmental crises. The World Health Organization defines health as physical, mental and social wellbeing (not only absence of disease), as the "status of full physical, mental and social effectiveness confirmed subjectively and objectively, also by medical examination" (Gaweł, 2003, p. 15; compare WHO Health... 1998, passim).

The healthy style of life is a system of combined behaviours, customs, habits that may influence the level of minimizing the risk of a premature development 
of specific diseases and are determined by social and cultural factors, as well as individual features (Gaweł, 2003, p. 23).

\section{Historical exemplifications of the Polish morality of daily life/lifestyle}

The process of social competences that include attitudes towards health and healthy lifestyle, also in free time, is strictly connected with acquiring cultural competences in the multigenerational sharing of the values of cultural heritage. Since culture constitutes a valuable hermeneutic key of understanding the sense/meaning of attitudes towards health and healthy lifestyle, it is worth reminding at least several examples from the Polish educational historiography (chronological criterion) connected with the qualitative interpretation of the category of health and healthy lifestyle and then to refer to applied aspects of education in this area in the 21th century.

In the period of renaissance it was assumed that every person is responsible for their health. Physical exercises were recommended to show care for the vital forces of the human body (Gaweł, 2003, p. 56). Mikołaj Rej (2003, v. sentence 1, p. 236) presented the idea of the image of a Polish nobleman. He justified the importance of the healthy lifestyle by stopping gluttony, drunkenness, because "time vanishes in drunkenness". In his opinion people should eat moderately, they should enjoy daily life and he expressed it with a metaphor: "try pouring vodka into the deer's mouth and feed it with golden tarts [...] and you'll see how long it will take before it falls on the ground. Or take a raven, sprinkle its nose with pepper, add wine: believe me, it won't coo long" (Rej, 2003, v. 2, p. 550). He condemned the abuse of all substances, especially, as he put it, overwhelming drunkenness (Rej, 2003, v. 2, p. 624). Piotr Zbylitowski $(1605$, p. 27) also wrote about the damages caused by the abuse of alcohol: "head hot with wine feels no trouble". He concluded: "drunkenness is ugly, so ugly, unfortunately. And how much trouble it brings all the time. [...] Temperance in all things is the best of all virtues. Sobriety, virtue of all virtues, the most glorious one" (Zbylitowski, 1608, pp. 34-35).

Łukasz Górnicki (2004, sentence 2, p. 127) defined the meaning of a healthy lifestyle as follows: "Who may find resting nice, if they did not feel tired first? Who may taste food, drink, sleep, if they did not feel hungry, thirsty or sleepy earlier?". The full value of the renaissance humanity in the Polish tradition of postulating the interpersonal balance was also presented by Jan Kochanowski in trifles "On a sleep" (he wrote about the meaning of leisure for a harmonious development of a human being and "On health", where he emphasized that health is a priceless gift, which should be valued and protected.

In the $17^{\text {th }}$ century the issue of a healthy lifestyle in harmony with nature was investigated by Jan Amos Komeński (1935, p. 98). He assumed that a human being has a long life, but people cannot use their vital forces responsibly and they do not care about their own health, they eat unhealthy food. He contained his opinion 
about the meaning of leisure in the natural system: "a tree needs to rest in some time spans [...] so that it does not have to bear new buds all the time, new flowers or fruit, but so that it also could digest the juices and strengthen its powers in this way. Therefore God ordered winter after summer to ensure resting to all that grows from the earth and from the soil" (Komeński, 1935, p. 101). He recommended observing nature, getting to know and learning the laws of nature with their application in daily life.

The issue of a healthy human development was also explained by Jędrzej Śniadecki in his work About physical upbringing of children, first published in 1805 in the "Wileński Journal", initially in the form of a book for mothers (Śniadecki, 1920). Whereas Jędrzej Kitowicz (2003, pp. 452-454) described the Polish custom of organizing feasts in the Republic of Poland. He stated that feasts were common in daily life of the Polish noblemen by writing that "there are few days without guests". Many meals were eaten and among hem there were the "bad guy's stew" and "mead", whereas the "beer barrel in the chimney - when good drunkards company gathered - did not remain for more than two hours" (Kitowicz (2003, pp. 455-495).

In the 19th century during the national slavery the value of traveling for pleasure and discovering the beauty of nature was appreciated. Seweryn Goszczyński (1958, p. 304) is the author of a journal entitled Travel journal to the Tatra mountains, in which he presented the creative description of the Tatra nature and the mountain people's culture. Bogusz Zygmunt Stęczyński, had similar interests, as he traveled by foot (for twenty years from the spring until the fall) with a notebook and a drawing paper in the Tatra and the Sudety mountains. In his poems entitled The Tatras and The Sudety he expressed his admiration for the natural beauty of nature and its positive influence on a human being's feeling (Stęczyński, 186o, pp. 48, 97; 1981, pp. 53, 74, 93). Adam Mickiewicz (1986, p. 282 and 330-359) in his gentry poem about the noblemen's lives Pan Tadeusz showed (among others) the patterns of behaviour, also in free time and the noble custom of hunting. Józef Dietl justified the healing power of nature in regaining vital forces. He stated that the human body has healing properties when optimal conditions of life are available. (Szpilczyński, 1977, p. 606). Healing and touristic values of nature were also described by a physician, co-founder of the Tatra Society, Tytus Chałubiński (1988, p. 76). Henryk Jordan, professor of medicine, had similar views on the matter and established Park of games and play for children and youths of all states (area for plays, games and sports available for youths and children).

Adam Asnyk (1923, p. 35) popularized the aesthetic value of nature and its therapeutic influence on human life during walks. The following quote may serve as an example: "the most various kinds of trees, bushes and plants created a living mosaic, which the walker can see, both the general harmony of a landscape as well as many single gracious details". He wrote poetic allegories about the beauty of the Tatra Mountains in the works entitled „Z podróży Dunajcem”, „Ranek w górach”, „Giewont”, „Kościeliska”, „Morskie Oko” (Asnyk, 1998, pp. 3-35). 
In the Polish culture, there are also esteemed descriptions of nature written by Zygmunt Gloger (1903, pp. 18-218). While traveling along Niemno, Vistula, Bug and Biebrza rivers not only did he visit the nearby landscapes, places and not only did he contemplate the beauty of nature, but he also gathered and subsequently rescued various old objects such as old tiles of medieval fortifications, flint arrow mainsails, old tools and vessels. He noted songs, proverbs and described the interiors of peasants' huts. He got to know the monuments of visited places, he enjoyed the birds signing. He stated: "I did not experience fatigue even for a while. Green wonderful areas everywhere" (Gloger, 1903, p. 8).

It should be emphasized that in the second half of the 19th century, in many magazines, there were descriptions of journeys with the purpose of not only encouraging the Polish society to visit beautiful and monumental places, but also to inspire the recognition of the fatherland, natural landscape and, what is important, social transformations in difficult conditions of national bondage. This tendency maintained in the modernist town culture of the first half of the 20 century. The activity of Stanisław Witkiewicz (1991, pp. 1, 4), painter, art critic, who would travel to Zakopane back in the nineties of the 19th century. He showed a strong relationship between a human being and nature and its developing influence on human health. He wrote: "whether it will be the sea, the mountains or great jungle [...] a human being rests here, pessimism is beaten". Creative expressions on this subject were also created by other poets, writers, for example Jan Kasprowicz, Kazimierz Przerwa-Tetmajer, Stefan Żeromski (1889, p. 44).

Jan Gwalbert Pawlikowski (1913, p. 7) pointed to the meaning of the health aspect of nature as the source of vital forces that shape spiritual balance. In his opinion the people of the town miss nature, they express their esteem for the environment with various means of expression (also artistic): they write, they paint, they compose musical works, they make patterns of plants like in the forest, they choose to rest in the natural environment (Pawlikowski, 1927, p. 3). Wincenty Lutosławski (1999, passim) was a great advocate of vacation walks in the fatherland. He opted for raising the national awareness thanks to the art, monuments of nature and upbringing for a balanced use of all goods (also alcohol). For this purpose he referred to the symbol of the temperance sash of the lodges of Templar Kights (Lutosławski, 1902, pp. 5-8). He recommended spiritual and physicalexercises, which served to shape the psychosomatic balance. Besides, in his opinion the religious faith is the creative power which supports the social development (Lutosławski, 1909, pp. 8-9).

In the second half of the 2oth century, in the postmodern culture, in relation with the paradigm/challenge of a "permanent becoming", perfecting of the subjective and objective identity of a one/the only thinking interpretation (Witkowski, 1997, pp. 37-315) free time and healthy lifestyle category of life was meaningful in social life. In the Universal Declaration of Human Rights adopted on 10 December 1948 by the General Assembly of the United Nations a number of rights which serve every person was specified. Among others it was stated (article 24) that every person is 
entitled to a holiday and rest, including "reasonable limitation of working hours and periodical paid holiday" (Universal Declaration of Human Rights 1989, p. 5-16). It certainly serves the balanced self-development/self-creation of a given human being in various areas, especially the areas of personal and professional life, also in free time.

\section{Applied aspects of the education for a healthy lifestyle in free time at the turn of the $20^{\text {th }}$ and the $21^{\text {st }}$ centuries}

As it was already mentioned in this paper, free time has culturally a creative meaning and it should be understood broadly. It is in the best social interest, because thanks to resting and therapeutic pleasure of a voluntary free time activities (for example reading, self-education, gathering, poetic/musical creation, playing an instrument, singing, dancing, play, cultural and educational games, voluntary work, traveling/ recreational tourism, playing outside, impression of works of art in museums, opera, theatre) may regenerate the vital powers of the body, which has a positive effect on the functioning of the community of human societies as a whole. Therefore it is so important to care for mental maturity (intellectual, emotional and social syntone) so that free time is not only an appreciated value, but also a subject of balanced attitudes: social, ideation, cultural, intellectual, intra- and interpersonal, existential, towards nature (in the following aspects: cognitive, emotional and behavioral).

Pedagogical rationality constitutes a reasonable justification of thinking and effective activity in the scope of knowledge about education, both in the process of explaining the surrounding reality and thinking about it. Pedagogical rationality may be considered statistically in the aspect of hermeneutic competence, which is created by experienced and recognized values and in the dynamic aspect with reference to practical interpretative activities. The following are criteria of rationality: technical (subjectivity), hermeneutic (interpretation of cultural symbols) (Szymański, 2000, p. 42), emancipative (demistifying) (Kwaśnica, 1987, passim).

In the nineties of the 2oth century Zbigniew Kwieciński (1992, p. 125-141; compare Kwaśnica, 1993, p. 82) stated that, as long as the idea of humanization of school facing the needs of a learner is not implemented by the educators mostly through communicative and emancipative rationality, it will remain a desideratum/a myth. It will constitute a specific social "mask" for educators with the adaptativeinstrumental rationality, who mastered the "narration of universal help", and in fact they realize the "hidden" and non-developing symbolical or structural violence. Social personality of youth and children constitutes a derivative quality of adults' social personality and if for example the "developmental isonomy trap" (society living in a difficult time of a system transformation) affects the adult society their children find it much more difficult to become mature enough to expect an equal treatment in various aspects of social life, also in free time. What is more, the structural violence has a tendency to strengthen itself. 
The educational process constitutes a purposeful sequence of activities (Palka, 1997, 63). Academic and social education for a healthy style of life in free time is carried out starting from kindergarten and home education with reference to many fields of personal development (for example aesthetics, mentality, morality, health, patriotism, citizenship, religion, ecology) in various organizational forms, such as: individual activity (uniform and diverse), collective and team activity both purposeful and intentional interpersonal episodes in individual borders of developmental abilities of the pupil and binding normative acts in this scope. If circumstances demand, in co-operation with specialists in pedagogy (for example special educators, deaf and hard-of-hearing specialists, teachers of the visually impaired), psychology and medicine.

In the creation of strategy/projects for education and personal development in a healthy style of life in free time it should be remembered that in social actions, apart from the substantial communication layer, the personal experience layer and the human relationship layer were separated (Wójcik, 200o, passim). Pursuant to the paradigm of subject education (Lewowicki, 1997, passim) educational activity may not be limited to the content (substantial layer), but also personal experiences/ emotions and social interactions of the pupils should be taken into account. Animation classes may be a valuable help in this area (for example communicative animation, integrative animation, cultural, relaxing, educational) also with the use of various methods of education (especially valorization and independent gaining of knowledge) and personal development (especially methods of modeling/methods of personal influence of the educator), as well as valuable educational means.

Every educator is a creator and if he or she creates wisely and builds "bridges not barriers", he or she frees the "biophilic potential of the 'to be' attitude" (E. Fromm), he or she acts on behalf of the pupil as a wise friend (Wolter, 2009, p. 59) on the foundation of cultural heritage. In the conditions of post-modern culture the subjective development "fundamentally connects with a chance for a human being, conditions of his or her development and creative action, both in effect of intentional educational processes as well as personal self-education" (Wojnar, 1997, p. 30) in a complex process of growing/maturing to a full and healthy humanity and a healthy style of life, also in free time.

\section{Conclusion}

Based on the presented theses the following conclusion may be formulated: The basis of the process of education and personal development for a healthy lifestyle in free time is the understandable symbolical situation of the normative culture patterns, symbolical and ideation culture of a given society. We need to remember that balanced and responsible support, both in form and content, necessary for every pupil in the development of his or her potential, self-development/self-creation 
(also in the aspect of free time) is one of the educational challenges. We also should be cognizant that this support operates in a specific space, place and time.

\section{References}

Asnyk, A. (1998). Poezje tatrzańskie (wybór/selection, opracowanie/elaboration G. Niewiadomy). Gdańsk: Wydawnictwo Zawrat w 160 rocznicę urodzin Adama Asnyka.

Asnyk, A. (1923). Wśród lasu, opiekunowie (wstęp/introduction W. Prokesch). LwówWarszawa-Poznań-Kraków-Lublin: „Lektor” Instytut Literacki.

Chałubiński, T. (1988). Sześć dni w Tatrach wycieczka bez programu (wstęp/introduction J. Kolbuszewski, historia tekstu/text history W.A. Wójcik). Kraków: Wydawnictwo Lekarskie.

Gaweł, A. (2003). Pedagodzy wobec wartości zdrowia. Kraków: Wydawnictwo Uniwersytetu Jagiellońskiego.

Gloger, Z. (1903). Dolinami rzek opis podróży wzdłuż Niemna, Wisły, Bugu i Biebrzy (przedmowa E. Orzeszkowa). Warszawa: Nakład Ferdynanda Hoesicka.

Goszczyński, S. (1958). Dziennik podróży do Tatrów (opracowanie/elaboration S. Sierotwiński). Wrocław-Kraków: Zakład Narodowy im. Ossolińskich.

Górnicki, Ł. (2004). Dworzanin polski. Tom 2 (opracowanie/elaboration R. Pollak). Wrocław: Zakład Narodowy im. Ossolińskich.

Kitowicz, J. (2003). Opis obyczajów za panowania Augusta III (opracowanie/elaboration R. Pollak). Wrocław: Zakład Narodowy im. Ossolińskich.

Komeński, J.A. (1935). Wielka dydaktyka (tłumaczenie/translation K. Remierowa). Warszawa, Lwów: Nakładem Naukowego Towarzystwa Pedagogicznego.

Kwaśnica, R. (1987). Dwie racjonalności. Od filozofii sensu ku pedagogice ogólnej. Wrocław: Instytut Kształcenia Nauczycieli im. W. Spasowskiego w Warszawie. Oddział Doskonalenia we Wrocławiu.

Kwaśnica, R. (1993). Pytanie o nauczyciela. Wrocław: Acta Universitatis Wratislaviensis, 0239-6661, no 1547. Prace Pedagogiczne, 0137-109699.

Kwieciński, Z. (1992). Socjopatologia edukacji. Warszawa: Polska Akademia Nauk. Instytut Rozwoju Wsi i Rolnictwa.

Kwilecki, K. (2011). Rozważania o czasie wolnym wybrane zagadnienia. Katowice: Górnośląska Wyższa Szkoła Handlowa im. Wojciecha Korfantego.

Lewowicki, T. (1997). Przemiany oświaty. Szkice o ideach i praktyce edukacyjnej. Warszawa: Wydawnictwo Żak.

Lutosławski, W. (1900). O wychowaniu narodowym. Kraków: Nakładem Księgarni S.A. Krzyżanowskiego.

Lutosławski, W. (1909). Religia w życiu narodowem. Warszawa: Nakład Przeglądu Narodowego.

Lutosławski, W. (1902). Z dziejów wstrzemięźliwości. Kraków: Nakładem Księgarni K. Wojnara. 
Matyjas, B. (2003). Czas wolny. W: Encyklopedia pedagogiczna XXI wieku. Tom 1 $A-F$ (słowo wstępne/foreword T. Pilch). Warszawa: Wydawnictwo Akademickie „Żak”.

Mickiewicz, A. (1986). Pan Tadeusz czyli ostatni zajazd na Litwie. Historia szlachecka $z$ roku 1811 i 1812 we dwunastu księgach wierszem. Warszawa: Książka i Wiedza.

Palka, S. (1997). Epistemologiczne podstawy ilościowego i jakościowego badania efektów kształcenia szkolnego. W: Epistemologiczne wyzwania współczesnej pedagogiki. Duraj-Nowakowa K., Gnitecki J. (red. nauk./scientific editing). Kraków: Wydawnictwo Naukowe Wyższej Szkoły Pedagogicznej.

Pater, R. (2015). Czas wolny w (dla) edukacji kulturalnej dzieci Free Time (for) the Education of Children. W: „Edukacja elementarna w teorii i praktyce. Czas wolny dzieci w wieku przedszkolnym wczesnoszkolnym” Tom 35 (2015), numer 1 (styczeń-marzec), kwartalnik EETP.

Pawlikowski, J.G. (1913). Kultura a natura, Warszawa-Lwów: Staraniem Sekcji Ochrony Tatr Towarzystwa Tatrzańskiego.

Pawlikowski, J.G. (1927). Słowo o międzynarodowej ochronie przyrody i jej tendencjach rozwojowych. „Ochrona Przyrody” 1927 (z. 7).

Pięta, J. (2008). Pedagogika czasu wolnego. Warszawa: Almamer Wyższa Szkoła ekonomiczna.

Powszechna Deklaracja Praw Człowieka (wstęp/introduction H. Samsonowicz) (1989). Warszawa: Wydane przez Biuro Informacji ONZ przy współpracy Polskiego Towarzystwa Przyjaciół ONZ.

Pytanie o nauczyciela, ed. by R. Kwaśnica (1993). Wrocław: Acta Universitatis Wratislaviensis, 0239-6661, no 1547. Prace Pedagogiczne, 0137-109699.

Rej, M. (2003). Żywot człowieka poczciwego. Tom 1 i 2 (opracowanie/elaboration J. Krzyżanowski). Wrocław: Zakład Narodowy im. Ossolińskich.

Stęczyński, B.Z. (1981). Sudety (wstęp/introduction J. Kolbuszewski). Jelenia GóraWrocław: Ossolineum Towarzystwo Przyjaciół Jeleniej Góry.

Stęczyński, B.Z. (1997). Tatry w dwudziestu czterech obrazach (reprint z 1860 roku). Wrocław: Wydawnictwo Wacław Bagieński.

Szpilczyński, S. (1977). Nauki medyczne, w: Historia nauki polskiej. Tom III 1795-1862. Suchodolski B. (red./scientific editing). Wrocław-Warszawa-Kraków-Gdańsk: Zakład Narodowy im. Ossolińskich, Wydawnictwo Polskiej Akademii Nauk.

Szymański, M.J. (200o). Studia i szkice z socjologii edukacji. Warszawa: Instytut Badań Edukacyjnych.

Śniadecki, J. (1920). O fizycznym wychowaniu dzieci (wstęp/introduction J. Korczak). Warszawa: b.n.w.

Tauber, D.R. (1998). Pedagogika czasu wolnego. Poznań: Wyższa Szkoła Hotelarstwa i Gastronomii.

Witkiewicz, S. (1991). Tatry w śniegu. W: Witkiewicz S., Zakopane w zimie. Tatry wśniegu (wstęp/introduction G. Niewiadomy). Gdańsk: Wydawnictwo „Zawrat”. 
Witkowski, L. (1997). Edukacja wobec sporów o (po)nowoczesność. Warszawa: Instytut Badań Edukacyjnych.

Who Health 21-Health for All in the 21st Century. (1998). Kopenhagen: European Health for All Series, Nr 6 WHO.

Wojnar, I. (1997). Aktualne procesy edukacji i kultury w Polsce i na świecie. W: Edukacja wobec wyzwań XXI wieku. Warszawa: Komitet Prognoz „Polska w XXI wieku” przy Prezydium PAN.

Wolski, A. (2009). Od redaktora. W: Kulturowe zachowania warunkujące dobrostan. Wolski A. (red./scientific editing). Lublin: Wydawnictwo NeuroCentrum w Lublinie.

Wolter, E. (2009). Podmiotowość jako kategoria pedagogiczna. „Paedagogia Christiana" 2/24 (2009).

Woronowicz, W., Apanel, D. (2010). Opieka -wychowanie - kształcenie. Moduły edukacyjne. Kraków: Oficyna Wydawnicza „Impuls”.

Wójcik, E. (2000). Metody aktywizujące w pedagogice grup. Kraków: Wydawnictwo Rubikon.

Zbylitowski, P. (1605). Schadzka ziemiańska. Kraków: b.n.w.

Żeromski, S. (1889). Puszcze jodłowa (wstęp/introduction A.J. Adamczyk). Kielce: Wydawnictwo Dom Książki.

\section{WYCHOWANIE DO ZDROWEGO STYLU ŻYCIA W CZASIE WOLNYM}

Streszczenie: Celem artykułu jest zaprezentowanie problematyki wychowania do zdrowego stylu życia na wybranych przykładach dziedzictwa kultury zachowań społeczeństwa polskiego, jako ideacyjnego fundamentu działań aplikacyjnych w kulturze ponowoczesnej na przełomie XX/XXI wieku. Problem badań jest osadzony w paradygmacie interpretatywnym nauk społecznych, humanistycznych. W procesie badawczym zastosowano metodę badań jakościowych: jakościowa analiza tekstu/analiza jakościowa dokumentów, w której istotne są hermeneutyczne rozumienie oraz interpretacja tekstu źródłowego. Podstawę analiz stanowią historyczne źródła drukowane (materiały pierwotne) oraz opracowania naukowe dotyczące problematyki wskazanej w tytule.

Słowa kluczowe: czas wolny; zdrowie; zdrowy styl życia; wychowanie; pedagogika czasu wolnego; historia wychowania. 